beginning of each year by the Oral Data Committee of the African Studies Association for the purpose of transcription, translation, annotation, copying, or indexing collections of oral data from Africa. (Grants are not offered for field collection.)

Application forms are available from the African Studies Association, 622 West II $3^{\text {th }}$ Street, New York, N.Y. 10025. They are due at the offices of the Association by i January I969, and the announcement of the first year's awards will be made before I February I969. Awards are not limited to American citizens or to members of the African Studies Association, though ultimate public deposit will be a condition of all grants-in-aid. In addition to the annual competition, small grants on an emergency basis may occasionally be made when special and temporary opportunities for transcription or translation occur during field research in Africa. Requests should be addressed to the Chairman, Oral Data Committee, in care of the Association's office in New York.

Since the programme of the Oral Data Committee is still in an experimental stage, the committee would appreciate hearing about the problems, experiences, and needs of fieldworkers and other users of oral data in any field of African Studies. Correspondence should be addressed to the chairman of the committee. Correspondence concerning the deposit of collections or the copying of collections already on deposit should be addressed directly to the Archives of the Traditional Music in Bloomington, Indiana.

\title{
Research on Economics of East and West African Agricultural Development
}

A seminar on this subject, jointly sponsored by the American Universities Research Program of the Agricultural Development Council, Inc. (NYC) and the Department of Agricultural Economics, Michigan State University, East Lansing, Michigan, was held at East Lansing on 9-14 June 1968. The Conference Chairman was Dr. Carl K. Eicher, Michigan State University, and the Rapporteur Mr. Dan Etherington, Food Research Institute, Stanford University.

The subjects discussed at the sessions were as follows: Agricultural Policy and Planning in East Africa; Current Research on West African Agricultural Development; Comparative Studies of East and West African Agricultural Development; Current Research on Agricultural Development in East Africa; Preliminary Observations on Population and Economic Development in East and West Africa; Evaluation of the Comparative Examination of East and West Agricultural Economics Research.

\section{Research at the University of South Africa, Pretoria}

THE following research is being pursued in the Department of Native Administration: Professor B. S. van As: policy with regard to urban native housing in Malawi, Zambia, Rhodesia, and South Africa; Mr.D. A. Kotze : the role of traditional institutions in African government, with special reference to local government in the Transkei and Lesotho; Mr. J. C. N. Mentz: factors influencing the functioning of urban local Bantu government; a typological study of the Urban Bantu Council of Welkom, South Africa; Mr. P. J. Hugo: political representation in multi-racial societies, with special reference to the Coloured population of South Africa; Mr. W. Bosman: administration of Bantu land tenure in the Bantu areas of South Africa, with special reference to the Bantu Affairs Commissioner's Area of Hammanskraal.

\section{Université d'Abidjan: Nowvelles de la Recherche}

Institut d'Ethno-sociologie:

M. Memel Fote: le système politique traditionnel des Adiukru comparé aux systèmes politiques traditionnels des peuples lagunaires; $M$. Niangoran Bouah: l'organisation politique des 